\title{
Gastric Cancer pT4b TNM Finding v8
}

National Cancer Institute

\section{Source}

National Cancer Institute. Gastric Cancer pT 4b TNM Finding v8. NCI Thesaurus. Code C133616.

Gastric cancer with tumor invading adjacent structures/organs. (from AJCC 8th Ed.) 